\title{
Dynamics of carbon pools in post-agrogenic sandy soils of southern taiga of Russia
}

\author{
Olga Kalinina*1, Sergey V Goryachkin¹, Nina A Karavaeva², Dmitriy I Lyuri² and Luise Giani
}

\begin{abstract}
Background: Until recently, a lot of arable lands were abandoned in many countries of the world and, especially, in Russia, where about half a million square kilometers of arable lands were abandoned in 1961-2007. The soils at these fallows undergo a process of natural restoration (or self-restoration) that changes the balance of soil organic matter (SOM) supply and mineralization.
\end{abstract}

Results: A soil chronosequence study, covering the ecosystems of 3,20,55, 100, and 170 years of self-restoration in southern taiga zone, shows that soil organic content of mineral horizons remains relatively stable during the selfrestoration. This does not imply, however, that SOM pools remain steady. The C/N ratio of active SOM reached steady state after 55 years, and increased doubly (from 12.5 - 15.6 to 32.2-33.8). As to the $\mathrm{C} / \mathrm{N}$ ratio of passive SOM, it has been continuously increasing (from 11.8-12.7 to 19.0-22.8) over the 170 years, and did not reach a steady condition.

Conclusion: The results of the study imply that soil recovery at the abandoned arable sandy lands of taiga is incredibly slow process. Not only soil morphological features of a former ploughing remained detectable but also the balance of soil organic matter input and mineralization remained unsteady after 170 years of self-restoration.

\section{Background}

Until recently, a lot of arable lands were abandoned in many countries of the world. Predominantly caused by economic crises, the most abandonment was found in Russia, reaching $578000 \mathrm{~km}^{2}$ in the years 1961-2007 [1-3]. As a consequence, the soils of these sites underwent the process of natural restoration or self-restoration.

A recent chronosequential study on the succession of vegetation, profile morphology, and soil properties of post-agrogenic sandy soils under self-restoration of the southern taiga zone in the European part of Russia showed that the vegetation developed towards spruce forest and the soils towards natural Podzols with an accumulation of thick raw humus layers [4]. Additional podzolization features were found in respect to morphology and chemical properties like $\mathrm{pH}$, exchangeable cations, and nutrition dynamics. Although these changes happened rather fast, the ploughing features were still evident after 170 years of self-restoration, as found in other studies $[1,2,5,6]$.

\footnotetext{
* Correspondence: oykalinina@mail.ru

1 Dept. Soil Sci. C-v-O. University of Oldenburg, Oldenburg, Germany Full list of author information is available at the end of the article
}

Since every land-use change causes a disturbance of the long-termed adjusted balance of soil organic matter (SOM) supply and mineralization, self-restoration also leads to alterations in the SOM dynamics. In respect of afforestation of former arable sites, the most evident effect on $\mathrm{C}$ sequestration was the net sink of atmospheric $\mathrm{CO}_{2}$ with $\mathrm{C}$ accumulation mainly in the growing trees and the forest floor [7-11]. The mineral soil was found to account for less than $1 \%$ of radio carbon accretion [10] and might be even less due to varying interrelations between initial soil organic carbon (SOC) pools and SOC dynamics trends in respect to environmental conditions $[12,13]$. Results on $\mathrm{C}$ sequestration of post-agrogenic sandy soils under self-restoration of the southern taiga zone in the European part of Russia also indicate an over all sink [4]. Decreased SOC stores of the $0.2 \mathrm{~m}$ mineral soil were overcompensated by increasing SOC stores of the raw humus layer, the latter rating $10 \%$ of the whole SOC stores after 55 years of self-restoration, and $40 \%$ after 100 years and $52 \%$ after 170 years, respectively.

Self-restoration does not only affect carbon sequestration but also influences the different functional carbon pools and qualities. These changes in SOM are already 
indicated by increasing $\mathrm{C} / \mathrm{N}$ ratios during self-restoration of post-agrogenic soils [4].

They are expected not to proceed consistently because they preferentially affect the SOM with a short turnover time corresponding to free particulate organic matter $(\mathrm{OM})$ and the $\mathrm{OM}$ of the sand and coarse silt fractions [14-16]. Diminishing plant OM transformation induced an accumulation of particulate SOM from poorly decomposed plant residues producing raw humus in Podzols $[11,17]$. Because of low bioturbation, this SOM is considered for the SOM dynamics of the mineral soil. Therefore, during self-restoration, decreasing particulate SOM from former land use is expected in the mineral soil and perhaps simultaneously, increasing particulate SOM from fine root litter supplied by newly established plants. Changes in SOM dynamics are also expected for the mineral bound fraction. John et al. [16] reported more mineral bound organic carbon $(\mathrm{OC})$ in cultivated soils than in forest topsoils. As discrete fractions show different times of decomposition in the range of 20-50 years for particulate SOM and about 100 years or more for mineral associated SOM $[15,16,18]$, this decrease is assumed to be a long-term one at the site of this investigation.

To obtain additional information on $\mathrm{C}$ dynamics and alterations of soils under self-restoration, this study was carried out with a focus on different functional carbon pools and their qualities. We used the same soil chronosequence, which has been previously investigated for changes of basic soil properties [4].

\section{Results}

The total SOC contents stayed relatively constant during self-restoration (Table 1). This was also obvious for the relictic ploughed horizons, showing a mean of $17.6 \mathrm{~g} \mathrm{~kg}^{-1}$ for the 3 years old soil under self-restoration and $15.4 \mathrm{~g}$ $\mathrm{kg}^{-1}$ for the 170 years old soil. Slight SOC enrichments were found in the newly developed Ah horizons 3-20 years after self-restoration with 23.7 and $29.9 \mathrm{~g} \mathrm{~kg}^{-1}$ respectively, The SOC contents of the newly developed albic horizons were 36.1 and 21.7 after 100 and 170 years of self-restoration, whereas it was 20.9 in the same horizon of the Albic Podzol.

To test the occurrence of young living roots and to exclude the residual character from former land use Glomalin-related soil protein (GRSP) concentration was measured. As Glomalin is a protein produced by arbuscular mycorrhizal fungi during colonization, Glomalin concentration is correlated to the abundance of metabolizing roots [19]. GRSP concentration was $2.1-2.7 \mathrm{mg} \mathrm{g}^{-1}$ in the former ploughed horizons of soils being 55,100 , and 170 years under self-restoration whereas it was $1.9-3.2 \mathrm{mg} \mathrm{g}$ 1 in the Ah, Ap horizons of the 3 and 20 years' soils under self-restoration.
The OC content of free particulate organic matter $(\mathrm{POM})$ in the light fraction $\left(<1.8 \mathrm{~g} \mathrm{~cm}^{-3}\right)$ was $38.9-75.3 \%$ of SOC (Table 1). The OC ratios of the particles' size $<20$ $\mu \mathrm{m}$ in the heavy fractions of the studied topsoils were in the range of 20.3 to $42.4 \%$ of SOC. Therefore, neither fraction showed a significant change during self-restoration. Occluded POM in the light fraction $\left(<1.8 \mathrm{~g} \mathrm{~cm}^{-3}\right)$ was not found. The $\mathrm{C} / \mathrm{N}$ ratios of free POM in the light fraction $\left(<1.8 \mathrm{~g} \mathrm{~cm}^{-3}\right)$ increased under self restoration: 13.8 - 16.8 - 33.0 - 27.9 - 32.6 (in the mean) after 3, 20, 55, 100 , and 170 years of abandonment. The $\mathrm{C} / \mathrm{N}$ ratio of the free POM in the light fraction $\left(<1.8 \mathrm{~g} \mathrm{~cm}^{-3}\right)$ of the Albic Podzol was with 36 in the mean remarkably high. The $\mathrm{C} /$ $\mathrm{N}$ ratios of $\mathrm{OM}$ of the particles size $<20 \mu \mathrm{m}$ in the heavy fraction $\left(>1.8 \mathrm{~g} \mathrm{~cm}^{-3}\right)$ also increased within self-restoration: 12.2 - $14.2-18.9-21.3-20.5$ (in the mean) after 3 , 20, 55, 100, and 170 years of abandonment. The Albic Podzol showed a $\mathrm{C} / \mathrm{N}$ ratio 27.4. IR spectroscopic analysis of the $\mathrm{OM}$ in the light fractions did not show differences within self-restoration in respect to the composition of the functional groups as well as to their relative rates (data not shown).

The OC contents in the sand and coarse silt size separates was $47.4-73.9 \%$ of SOC (Table 2). The OC contents in the fine silt and clay fraction were in a range of 12.5 to $34.4 \%$ of SOC. As a result, both fractions did not show a significant change during self-restoration. The $\mathrm{N}$ contents in the sand size fractions of ploughing horizons were under detecting limit from 3 years of self-restoration and thereafter (Table 3). The $\mathrm{C} / \mathrm{N}$ ratios of OM of the fine-silt and clay fraction also increased within self-restoration but with less extent, showing $\mathrm{C} / \mathrm{N}$ ratios of 12 (mean values) at the beginning and 20 at the end of the chronosequntial observation for the silt and 11 and 15 for the clay fraction, respectively.

\section{Discussion}

This chronosequence showed an enrichment in SOC during self-restoration [4], which was caused by the development of an organic surface horizon and not by changes within the mineral horizons (Table 1). In the mineral horizons only slight modifications and peculiarities were observed, including enrichment in the newly developed Ah horizons 3-20 years after self-restoration, relatively high $\mathrm{C}$ contents within the newly developed albic horizons compared to natural Podzols [20], and relatively constant $\mathrm{C}$ contents within relict ploughed horizons. The latter confirms the morphological findings of long existing Ap features and corresponds to the high phosphorus contents even after an abandonment time of 170 years [4] and high root densities. Consequently, the former ploughed horizons act as a favoured rooting zone for the newly established vegetation. This assumption was confirmed by the occurrence of high Glomalin- 
Table 1: Contents of total organic carbon and $\mathrm{C} / \mathrm{N}$ ratios, free particulate organic matter (free $\mathrm{POM}$ ) of the density fraction $<1.8 \mathrm{~g} \mathrm{~cm}^{-3}$ and the mineral associated organic matter $(<20 \mu \mathrm{m})$ of the density fraction $>1.8 \mathrm{~g} \mathrm{~cm}^{-3}$ of the topsoils after 3 , 20, 55, 100, and 170 years under self-restoration and of an Albic Podzol, never been cultivated.

\begin{tabular}{|c|c|c|c|c|c|c|c|c|c|}
\hline \multirow[t]{2}{*}{ Horizon } & \multirow[t]{2}{*}{ Depth } & C & \multirow[t]{2}{*}{$\mathbf{C} / \mathbf{N}$} & \multicolumn{3}{|c|}{$\begin{array}{l}\text { Free POM of the density fraction }<1.8 \mathrm{~g} \\
\mathrm{~cm}-3\end{array}$} & \multicolumn{3}{|c|}{$\begin{array}{l}\text { Mineral associated } \mathrm{OM}(<20 \mu \mathrm{m}) \text { of the } \\
\text { density fraction }>1.8 \mathrm{~g} \mathrm{~cm}-3\end{array}$} \\
\hline & & g kg-1 & & $\%$ of soil & $\%$ of SOC & $\mathbf{C} / \mathbf{N}$ & $\%$ of soil & $\%$ of SOC & $C / N$ \\
\hline \multicolumn{10}{|c|}{3 years } \\
\hline \multirow[t]{2}{*}{ Ah } & $10(12)^{(1)}$ & 23.7 & 15.6 & 1.33 & 56.2 & 12.5 & 0.62 & 26.3 & 12.1 \\
\hline & 22 & 19.6 & 15.1 & 1.11 & 56.6 & 13.4 & 0.62 & 31.7 & 12.2 \\
\hline Ap1 & 33 & 19.1 & 16.5 & 0.81 & 42.6 & 12.7 & 0.48 & 25.2 & 12.7 \\
\hline Ap2 & 40 & 8.1 & 16.6 & 0.35 & 42.7 & 15.6 & 0.24 & 30.0 & 11.8 \\
\hline \multicolumn{10}{|c|}{20 years } \\
\hline $\mathrm{Ah}$ & 2 & 29.9 & 14.6 & 2.25 & 75.3 & 14.9 & 0.61 & 20.3 & 13.7 \\
\hline Ap1 & 18 & 14.9 & 14.1 & 0.69 & 46.1 & 17.3 & 0.50 & 33.5 & 14.4 \\
\hline Ap2 & $25(28)$ & 13.7 & 15.6 & 0.73 & 53.2 & 18.3 & 0.53 & 38.6 & 14.4 \\
\hline \multicolumn{10}{|c|}{55 years } \\
\hline Ah-E & 1 & nd & nd & nd & nd & nd & nd & nd & nd \\
\hline Ap1 & 8 & 18.2 & 27.2 & 1.13 & 62.0 & 32.2 & 0.54 & 29.6 & 18.9 \\
\hline Ap2 & 19 & 12.3 & 27.0 & 0.68 & 55.1 & 33.8 & 0.39 & 32.0 & 18.8 \\
\hline \multicolumn{10}{|c|}{100 years } \\
\hline$E$ & 2 & 36.1 & 28.6 & 2.46 & 68.0 & 27.4 & 0.86 & 23.8 & 21.2 \\
\hline Bsh & $5(9)$ & 26.5 & 26.5 & 1.08 & 40.8 & 30.6 & 0.93 & 35.3 & 22.4 \\
\hline Ap & 20 & 20.0 & 30.3 & 1.03 & 51.3 & 25.6 & 0.85 & 42.4 & 20.4 \\
\hline \multicolumn{10}{|c|}{170 years } \\
\hline$E$ & 2 & 21.7 & 31.2 & 1.53 & 70.5 & 27.9 & 0.54 & 24.9 & 19.0 \\
\hline Bsh & 6 & 20.6 & 28.3 & 1.35 & 65.6 & 32.4 & 0.59 & 28.8 & 19.8 \\
\hline Ap & 15 & 15.4 & 41.8 & 1.05 & 68.3 & 37.6 & 0.49 & 31.8 & 22.8 \\
\hline \multicolumn{10}{|c|}{ Albic Podzol } \\
\hline$E$ & $6(8)$ & 20.9 & 38.1 & 1.56 & 74.5 & 40.3 & 0.48 & 23.1 & 28.3 \\
\hline Bsh & 10 & 26.4 & 35.7 & 1.03 & 38.9 & 35.7 & 0.85 & 32.2 & 26.5 \\
\hline
\end{tabular}

related soil protein (GRSP) concentrations. Generally, the SOC contents of the mineral horizons did not change during self-restoration, indicating quantitatively balanced carbon dynamics during this process.

Occluded POM in the light fraction $\left(<1.8 \mathrm{~g} \mathrm{~cm}^{-3}\right)$ was not found, confirming the morphological findings of no aggregates in the studied soils.

With larger amounts in the top than in the subsoils, the highest OC content was found for free POM in the light fraction $\left(<1.8 \mathrm{~g} \mathrm{~cm}^{-3}\right)$ and in the sand and coarse silt size separates (Table 1,2). Composed of macroorganic matter from plant and animal origin [14], this SOC refers to the active and intermediate pool if charcoal is negligible with a short turnover time from 1 to 100 years [18]. Although a lower amount of active and intermediate $\mathrm{OC}$ pools in the arable soil than in the forest soil have been documented in several studies [7,16,21-23], we did neither find increasing SOC in the free POM of the light fraction $\left(<1.8 \mathrm{~g} \mathrm{~cm}^{-3}\right)$ nor in the sand and coarse silt size separates with increasing duration of self-restoration (Table 1, 2). As previously stated, we assume that the temporal constant amounts of these fractions in the mineral topsoil during self-restoration were caused by compensation of the loss of these fractions from the agronomic phase via mineralization and subsequent humification of newly developing roots. These fractions show an adjusted car- 
bon balance although mineralization and carbon sequestration occurred, confirming other studies [24-26] which state, that the light fraction is not an universal indicator in relation to land use change.

The OC of the heavy fraction $\left(>1.6-2.0 \mathrm{~g} \mathrm{~cm}^{-3}\right)$ and finesilt and clay fraction includes organo-clay complexes and mineral grains coated with OM, representing a stable SOC or passive pool $[14,18]$ with turnover times of 10 100 years and more for $\mathrm{OC}$ in the fine-silt and definitely more than 100 years in the clay fraction. Consequently, OC of the particles size $<20 \mu \mathrm{m}$ released from density fraction $>1.8 \mathrm{~g} \mathrm{~cm}^{-3}$ and the $\mathrm{OC}$ of the fine silt and clay fraction, investigated in this study, compose a stable OC pool with long turnover times. According to John et al. [16], a decrease of this pool was expected for the studied chronosequence. Nevertheless, the OC ratios of the particles' size $<20 \mu \mathrm{m}$ in the heavy fractions of the studied topsoils were in the similar range to the OC contents in the fine silt and clay fraction (Table 1, 2), showing no quantitative alterations of the stable $\mathrm{OC}$ pools with increasing duration of self-restoration which was unexpected because of increasing podzolisation dynamics but indicates once again an adjusted carbon balance.

The $\mathrm{C} / \mathrm{N}$ ratios of free POM in the light fraction $(<1.8 \mathrm{~g}$ $\mathrm{cm}^{-3}$ ) increased within self restoration (Table 1 ). These $\mathrm{C} /$ $\mathrm{N}$ ratios were expected to reach the value of the Albic Podzol (Table 1) but because of particular charcoal enrichment in the latter [4] they did not. The increase of $\mathrm{C} / \mathrm{N}$ ratios in these fractions resulted from increasing mineralization of agriculture-derived SOM and from the gradual input of qualitatively different organic material with low nitrogen concentration as discussed above. The nitrogen being released in mineral topsoil due to SOM mineralization is assimilated by the vegetation, creating a loss for the mineral soil [17]. As plant available phosphorus and potassium showed the same behaviour within this chronological sequence [4] an over-all shifting of the source of plant nutrients upwards to the forest floor was observed and documented in respect of principle raw humus formation processes by Chertov [27] and Chertov et al. [28].

Although no quantitative modifications of total SOM was observed, the changing $\mathrm{C} / \mathrm{N}$ ratios of free POM in the light fraction $\left(<1.8 \mathrm{~g} \mathrm{~cm}^{-3}\right)$ reflected qualitative alterations during self-restoration. This process could not be seen via IR spectroscopic analysis (data not shown). Highest and no more increasing $\mathrm{C} / \mathrm{N}$ values, achieved after 55 years of self-restoration (Table 1), indicated a new qualitative $\mathrm{OC}$ balance being present after that time. The $\mathrm{N}$ content in the sand size fractions of ploughing horizons was under detecting limit (Table 3), indicating partial rotation of an active OC pool already after 20 years of self-restoration. Short rotation times were also found for other environmental conditions [16,29]. For this study, the quick SOM rotation is considered to be due to "fresh" and easy decomposable macroorganic residues being characteristic of these OC fractions [14] in combination with accelerated acidification within this chronosequence [4], the latter also discussed by Chertov and Menshikova [30].

Qualitative changes in SOM within self-restoration were also found by increasing $\mathrm{C} / \mathrm{N}$ ratios for $\mathrm{OM}$ of the particles' size $<20 \mu \mathrm{m}$ in the heavy fraction $\left(>1.8 \mathrm{~g} \mathrm{~cm}^{-3}\right)$ (Table 1) and for $\mathrm{OM}$ of the fine-silt and clay fraction (Table 3). Lower $\mathrm{C} / \mathrm{N}$ ratios with decreasing grain sizes indicate less changes of SOM in the same order. These results confirm that SOM changes also affect the stable OC pool, also reported by others [16,23,29,31], showing mean ages of stable SOC in the range from 50 to 260 years. According to the $\mathrm{C} / \mathrm{N}$ ratios in the heavy fraction and fine-silt clay fractions, the first clear qualitative alterations of the stable OC pool found in this study occurred after 55 years of self-restoration. This alteration might be due to portions of rapid cycling $C$, being amongst the heavy fraction with long turnover times according to Golchin at al. and Swanston et al. [32-34], in combination with quick podzolisation found for this chronosequence [4], as already discussed above. Supply might be induced by highly decomposed OM from root litter and by leaching of highly oxidized water-soluble organic products from the forest floor into the mineral soil horizons and stabilisation therein by association with mineral phases [35]. Although the initiation was quick, "a complete new qualitative balance" of the stable SOM was not achieved within 170 years of self-restoration. This is shown by the $\mathrm{C} / \mathrm{N}$ ratios of $\mathrm{OM}$ of the particles' size $<20 \mu \mathrm{m}$ in the heavy fraction $\left(>1.8 \mathrm{~g} \mathrm{~cm}^{-3}\right)$ and in the fine-silt and clay fractions at the end of the chronosequence (Table 1, 3), being lower than those of the Albic Podzol.

\section{Conclusion}

Although the sandy post-agrogenic soils in the southern Taiga sub-zone of European Russia indicated a carbon sink during self-restoration by increasing carbon sequestration within the developing organic surface layers, the mineral horizons showed only small alterations in total $\mathrm{OC}$ contents and no quantitative but qualitative modifications in respect of different functionally $\mathrm{OC}$ pools. The constant quantities are supposed to result from simultaneously running supply and mineralization processes. The changing qualities indicate the formation of "a new balance" of active SOM within some decades, whereas this process is not yet completed for the passive SOM after 170 years of self-restoration. Also expressed by remaining soil morphological ploughing features, this study confirms that carbon dynamics are not balanced after 170 years of self-restoration. Soil recovery from agriculture is a long-term or infinite process. 
Table 2: Contents of organic carbon within the grain size fractions of the topsoils after $3,20,55,100$, and 170 years under self-restoration and of an Albic Podzol, never been cultivated.

\begin{tabular}{|c|c|c|c|c|c|c|c|}
\hline \multirow{4}{*}{ Horizon } & \multirow[b]{3}{*}{ Depth } & \multicolumn{6}{|c|}{ OC content in grain size } \\
\hline & & \multicolumn{2}{|c|}{ Sand } & \multicolumn{3}{|c|}{ Silt } & \multirow{2}{*}{$\begin{array}{c}\text { Clay } \\
<0.002 \mathrm{~mm}\end{array}$} \\
\hline & & $\begin{array}{c}2.0-0.2 \\
\mathrm{~mm}\end{array}$ & $\begin{array}{c}0.2-0.063 \\
\mathrm{~mm}\end{array}$ & $\begin{array}{c}0.063- \\
0.020 \mathrm{~mm}\end{array}$ & $\begin{array}{c}0.020- \\
0.0063 \mathrm{~mm}\end{array}$ & $\begin{array}{c}0.0063- \\
0.002 \mathrm{~mm}\end{array}$ & \\
\hline & $\mathbf{c m}$ & \multicolumn{6}{|c|}{$\%$ of SOC } \\
\hline \multicolumn{8}{|c|}{3 years } \\
\hline $\mathrm{Ah}$ & $10(12)^{(1)}$ & 33.0 & 19.3 & 21.6 & 8.4 & 10.8 & 6.3 \\
\hline \multirow[t]{2}{*}{ Ap1 } & 22 & 34.6 & 15.8 & 22.2 & 5.7 & 13.9 & 7.5 \\
\hline & 33 & 35.0 & 9.5 & 16.4 & 6.9 & 10.8 & 8.7 \\
\hline Ap2 & 40 & 39.1 & 6.5 & 11.1 & 8.2 & 14.1 & 13.1 \\
\hline \multicolumn{8}{|c|}{20 years } \\
\hline $\mathrm{Ah}$ & 2 & 38.9 & 12.3 & 20.5 & 8.6 & 10.4 & 8.3 \\
\hline Ap1 & 18 & 20.4 & 10.5 & 17.1 & 12.5 & 16.6 & 15.2 \\
\hline Ap2 & $25(28)$ & 22.5 & 9.4 & 21.2 & 12.2 & 21.3 & 13.1 \\
\hline \multicolumn{8}{|c|}{55 years } \\
\hline Ah-E & 1 & $\mathrm{Nd}$ & nd & nd & nd & nd & nd \\
\hline Ap1 & 8 & 32.2 & 6.8 & 10.1 & 12.3 & 11.4 & 9.1 \\
\hline Ap2 & 19 & 24.4 & 7.8 & 15.2 & 21.7 & 13.6 & 13.3 \\
\hline \multicolumn{8}{|c|}{100 years } \\
\hline $\mathrm{E}$ & 2 & 43.1 & 3.3 & 23.9 & 7.2 & 13.1 & 9.1 \\
\hline Bsh & 5 & 41.3 & 5.1 & 15.2 & 15.3 & 10.9 & 6.8 \\
\hline Ap & 10 & 37.1 & 6.5 & 16.4 & 23.6 & 8.9 & 7.0 \\
\hline \multicolumn{8}{|c|}{170 years } \\
\hline$E$ & 2 & 50.1 & 4.4 & 14.5 & 9.0 & 13.8 & 8.1 \\
\hline Bsh & 6 & 31.2 & 4.9 & 16.2 & 12.7 & 14.1 & 9.3 \\
\hline Ap & 15 & 30.5 & 9.1 & 17.3 & 16.4 & 10.1 & 13.8 \\
\hline \multicolumn{8}{|c|}{ Albic Podzol } \\
\hline $\mathrm{E}$ & $6(8)$ & 41.6 & 5.2 & 16.7 & 13.3 & 12.6 & 10.4 \\
\hline Bsh & 10 & 35.4 & 7.3 & 8.8 & 6.3 & 6.0 & 6.5 \\
\hline
\end{tabular}

nd - not determined

(1) Depths descriptions in parentheses indicate partly thicker horizons

\section{Methods}

\section{Site of investigation}

The study was done at the same sites where Kalinina et al. [4] conducted their investigation. It was located in the southern boreal sub-zone of the European part of Russia nearly $12-30 \mathrm{~km}$ south of the town Valday. Valday is situated at the federal highway M10, connecting Moscow with St. Petersburg, both being roughly $400 \mathrm{~km}$ apart.

Geographically, the investigation site is a part of the Valday Hills on the east European plain. The average annual temperature is $+3.2^{\circ} \mathrm{C}$, the annual precipitation is $714 \mathrm{~mm}$, and the frost-free period covers 128 days [36]. The Valday Hills were formed by late Weichselian end moraines, consisting of hills and many lakes in the depressions. Loamy to clayey as well as sandy sediments constitute the soil development. The latter were chosen for this study. For the chronosequential approach of this study, sites different in self-restoration time but comparable in soil texture, climate, and land-use history were selected. Subsequent sampling sites were chosen from 
Table 3: $\mathrm{C} / \mathrm{N}$ ratios of the organic matter within the grain size fractions of the topsoils after $3,20,55,100$, and 170 years under self-restoration and of an Albic Podzol, never been cultivated.

\begin{tabular}{|c|c|c|c|c|c|c|c|}
\hline \multirow{5}{*}{ Horizon } & \multirow{5}{*}{ Depth cm } & \multicolumn{6}{|c|}{$\mathrm{C} / \mathrm{N}$ ratios in grain size } \\
\hline & & \multicolumn{2}{|c|}{ Sand } & \multicolumn{3}{|c|}{ Silt } & \multirow{3}{*}{$\begin{array}{l}\text { Clay } \\
<0.002\end{array}$} \\
\hline & & \multirow{2}{*}{$\begin{array}{c}\begin{array}{c}\text { Coarse/ } \\
\text { Medium }\end{array} \\
2.0-0.2\end{array}$} & Fine & Coarse & Medium & Fine & \\
\hline & & & $0.2-0.063$ & $0.063-0.020$ & $\begin{array}{l}0.020- \\
0.0063\end{array}$ & $\begin{array}{c}0.0063- \\
0.002\end{array}$ & \\
\hline & & \multicolumn{6}{|c|}{$\mathbf{m m}$} \\
\hline \multicolumn{8}{|c|}{3 years } \\
\hline Ah & $10(12)^{(1)}$ & 31.4 & 28.8 & 14.0 & 12.9 & 12.0 & 10.7 \\
\hline \multirow[t]{2}{*}{ Ap1 } & 22 & 25.0 & 24.2 & 14.2 & 12.1 & 12.0 & 11.2 \\
\hline & 33 & 34.7 & nd & 14.9 & 14.3 & 12.0 & 10.9 \\
\hline Ap2 & 40 & nd & nd & 23.2 & 14.9 & 12.0 & 9.6 \\
\hline \multicolumn{8}{|c|}{20 years } \\
\hline Ah & 2 & 21.0 & 24.5 & 16.5 & 13.2 & 12.4 & 8.3 \\
\hline Ap1 & 18 & nd & nd & 19.0 & 15.5 & 13.5 & 9.2 \\
\hline Ap2 & $25(28)$ & nd & nd & 21.3 & 18.0 & 15.5 & 10.1 \\
\hline \multicolumn{8}{|c|}{55 years } \\
\hline Ah-E & 1 & nd & nd & nd & nd & $\mathrm{Nd}$ & nd \\
\hline Ap1 & 8 & nd & nd & 38.9 & 24.2 & 23.8 & 13.2 \\
\hline Ap2 & 19 & nd & nd & 45.2 & 26.3 & 24.2 & 15.0 \\
\hline \multicolumn{8}{|c|}{100 years } \\
\hline $\mathrm{E}$ & 2 & nd & nd & 29.8 & 30.4 & 21.7 & 18.9 \\
\hline Bsh & 5 & nd & nd & 32.0 & 26.7 & 21.5 & 15.1 \\
\hline Ap & 10 & 36.7 & nd & 30.9 & 24.0 & 21.6 & 13.7 \\
\hline \multicolumn{8}{|c|}{170 years } \\
\hline E & 2 & 53.1 & 42.8 & 24.0 & 24.4 & 18.5 & 14.8 \\
\hline Bsh & 6 & nd & nd & 30.5 & 28.6 & 17.1 & 14.6 \\
\hline Ap & 15 & nd & nd & 46.9 & 29.9 & 24.9 & 17.5 \\
\hline \multicolumn{8}{|c|}{ Albic Podzol } \\
\hline E & $6(8)$ & nd & nd & 44.6 & 38.0 & 28.5 & 17.7 \\
\hline Bsh & 10 & nd & nd & 31.6 & 26.8 & 22.9 & 17.5 \\
\hline
\end{tabular}

nd - not determined

(1) Depths descriptions in parentheses indicate partly thicker horizons

information obtained from topographic and geological maps, historical literature, and personal communication with local people. Having found adequate sites, five postagrogenic Podzols profiles of different self-restoration ages were dug in September 2007. Frequent Purckhauer drilling ensured that all profiles were representative of the sites. The chronosequential catena covered 3, 20, 55, 100, and 170 years of self-restoration. For precise locations and photos of the soil profiles see Kalinina et al. [4]. The sand percentage of all soils was $>85 \%$ and the clay fraction $\leq 2 \%$, indicating their pedological similarity. An Albic Podzol, which had never been under agricultural use, was included as a control. Soil morphology was described according to the Russian taxonomy [37] and World Refer- 
ence Base of Soil Resources (WRB) [38]. Bulk and volume samples were taken in triplicate from every horizon; the former ploughed horizons were additionally sampled at $10 \mathrm{~cm}$ intervals with increasing depths.

\section{Glomalin-related soil protein extraction}

Glomalin-related soil protein (GRSP) was extracted following the method of Wright and Upadhyaya [39], modified by Halvorson \& Gonzales [40]. Briefly, $2 \mathrm{~g}$ of soil were extracted by a total volume of $50 \mathrm{ml} 50 \mathrm{mM}$ diphosphate (adjusted to $\mathrm{pH} 8.0$ ) at $128^{\circ} \mathrm{C}$ during four extraction cycles, each lasting 1 hour. The pooled extract was centrifuged to remove soil particles and protein concentration determined by the Bradford assay [41] using BSA (bovine serum albumin) as a standard.

\section{Density and particle size fractionation}

The procedure was conducted in duplicate to obtain free particulate organic matter (POM) and occluded POM of the light fraction $\left(<1.8 \mathrm{~g} \mathrm{~cm}^{-3}\right)$ and fraction of particles $<20 \mu \mathrm{m}$ of the heavy fraction $\left(>1.8 \mathrm{~g} \mathrm{~cm}^{-3}\right)$ [42]. To avoid slaking, a $30 \mathrm{~g}$ air-dried soil sample $<2 \mathrm{~mm}$ was capillarysaturated and then immersed in deionised water on a 20 $\mu \mathrm{m}$ mesh sieve for $5 \mathrm{~min}$. The sieve was gently stirred on a rotating shaker (Laborshake Gerhardt Bonn) for 100 revolutions at a frequency of $55 \mathrm{rpm}$, dried at $40^{\circ} \mathrm{C}$, weighed, and the soil material was transferred to a centrifuge tube together with sodium polytungstate at a density of $1.8 \mathrm{~g} \mathrm{~cm}^{-3}$ (TC-Tungsten Compounds, Germany). The filling level was $2 / 3$ of the tube. The tube was handshaken ten times, and then centrifuged at $1200 \mathrm{~g}$ for 10 $\mathrm{min}$. The supernatant was washed with deionised water onto a paper filter (weight band Rotilabo) until the electrical conductivity dropped to $<50 \mu \mathrm{S} \mathrm{cm}^{-1}$. The remaining solution was filtered through a Glass Microfibre filter (GF/A) (referred to as free POM of the light fraction $(<1.8$ $\left.\mathrm{g} \mathrm{cm}^{-3}\right)$ ). The residual soil material was dispersed ultrasonically (HF-Generator GM-2200, Sonotrode VS 70T, Bandelin) with energy of $450 \mathrm{~J} \mathrm{ml}^{-1}$ for complete dispersion of soil micro aggregates [43]. The instrument was calibrated calorimetrically every 4 weeks according to North [44]. The dispersed soil was re-sieved at $20 \mu \mathrm{m}$. The material on the sieve was dried and treated as above to separate the occluded POM, which was not found. The fine fraction $<20 \mu \mathrm{m}$ was obtained by shaking a horizontal shaker at the beginning of the procedure and the fine fraction $<20 \mu \mathrm{m}$ gained after re-sieving the ultrasonically dispersed soil was combined and obtained by centrifugation by $4000 \mathrm{~g}$ for $18 \mathrm{~min}$. The supernatant was removed and the settled sample was washed intensively with deionised $\mathrm{H}_{2} \mathrm{O}$. The procedure was repeated until the electrical conductivity was $<50 \mu \mathrm{S} \mathrm{cm}^{-1}$ and the supernatant was clear. Thereafter, the sample was dried at $40^{\circ} \mathrm{C}$ and weighed (referred to mineral-associated OC $(<20$ $\mu \mathrm{m})$ of the heavy fraction $\left(>1.8 \mathrm{~g} \mathrm{~cm}^{-3}\right)$. All fractions were analyzed for total $\mathrm{C}$ and $\mathrm{N}$.

The free POM of the light fraction was additionally analyzed by infrared spectroscopy (FTS 7, Fa. Bio-Rad). Duplicate samples of 3-4 mg were ground with $100 \mathrm{mg}$ $\mathrm{KBr}$ and pressed $(8 \mathrm{t})$ to a pellet. The subsequent measurements were carried out in the mid-infrared area (225 $\left.-4000 \mathrm{~cm}^{-1}\right)$. The spectra were transformed into their real OC quantities of total C. The interpretation of the IR spectra was done according to Stevenson [45], Fookeu [46] and Senesi et al. [47].

\section{Grain-size fractionation}

Grain-size fractionation was done according to Kaiser et al. [48]. Destruction of aggregates and sample dispersion was achieved by a two-step ultrasonication (HF-Generator GM-2200, Sonotrode VS 70T, Bandelin). The instrument was calibrated calorimetrically every 4 weeks according to North [44]. The energy used for separating sand particles $>200 \mu \mathrm{m}$ was $60 \mathrm{~J} \mathrm{ml}^{-1}$. The energy input for the second dispersion step was $440 \mathrm{~J} \mathrm{ml}^{-1}$. Sand and coarse silt particles $(>20 \mu \mathrm{m})$ were separated by wet-sieving. Medium silt $(20-6.3 \mu \mathrm{m})$ and fine silt $(6.3-2 \mu \mathrm{m})$ fractions were recovered by sedimentation. The clay-size particles $(<2 \mu \mathrm{m})$ were separated by centrifugation at $4400 \mathrm{~g}$ for $20 \mathrm{~min}$. Then, the particle-size separates were dried at $105^{\circ} \mathrm{C}$ and analyzed for total $\mathrm{C}$ and $\mathrm{N}$.

The sum of the fractions is lower than $100 \%$ because of the specification of the fractionation technique: OC measurement in many fractions, OC loses, due to sodium polytungstate, application [32,49-52].

Carbon and nitrogen contents in dry soil pellets were determined after combustion and spectrometric measurements with a $\mathrm{C} / \mathrm{N} / \mathrm{S}$ analyser (CHNS-Analyser Flash EA) within the density and particle size fractions $<20 \mu \mathrm{m}$ as well as within the grain-size fractions (sand, silt, clay).

Unless stated otherwise, the data were based on three replicates; the standard deviations were always less than $10 \%$ of the mean.

\section{Competing interests}

The authors declare that they have no competing interests.

\section{Authors' contributions}

OK carried out literature research, participated in soil sampling, performed soil analysis, and drafted the manuscript. SVG and DIL conceived of the project idea, carried out the study of historical land use, participated in soil sampling. NAK helped in characterisation of the soils. LG is participated in coordination of the study and its design, and drafted the manuscript. All authors read and approved the final manuscript.

\section{Acknowledgements}

This work was supported by the Deutsche Forschungsgemeinschaft by grant Gl 17120-1. We thank Marie Spohn for the analysis of Glomalin, Gunda Sängerlaub, and Brigitte Rieger for their technical assistance.

\section{Author Details}

'Dept. Soil Sci. C-v-O. University of Oldenburg, Oldenburg, Germany and Institute of Geography, Russian Academy of Sciences, Moscow, Russia 
Received: 25 January 2010 Accepted: 26 April 2010

Published: 26 April 2010

\section{References}

1. Lyuri DI, Karavaeva NA, Nefedova TG, Konyushkov BD, Goryachkin SV: SelfRestoration of Post-Agrogenic Soils: Recent Process of Late Antropocene. Abstracts of 18th World Congress of Soil Science. Session 1.0B Soil Change in Anthropocence 2006:27-2.

2. Lyuri DI, Goryachkin SV, Karavaeva NA, Nefedova TG, Denisenko EA: Regularities of agricultural land withdrawal in Russia and in the world and processes of post-agrogenic development of fallows. In Agroecological status and prospects of use of lands of Russia withdrawn from active agricultural rotation Edited by: Ivanov AL. Moscow: Dokuchaev Soil Science Institute; 2008:45-71. (in Russian)

3. Ramankutty N: Global land-cover change: Recent progress, remaining challenges. In Land-use and land-cover change Edited by: Lambin EF, Geist HJ. Berlin: Springer; 2006:9-41.

4. Kalinina O, Goryachkin SV, Karavaeva NA, Lyuri DI, Najdenko L, Giani L: Self-restoration of post-agrogenic sandy soils in the southern taiga of Russia: Soil development, nutrient status, and carbon dynamics. Geoderma 2009, 152:35-42.

5. Kalinina O, Giani L: Degradation von Plaggeneschen und Konsequenzen für ihre ökologische Bewertung. Mitteilungen Deutsche Bodenkundliche Gesellschaft 2006, 108:105-106.

6. Lüst C, Giani L: Merkmale von Böden unter rezenten Wäldern, die auf ehemals landwirtschaftlich genutzten Flächen stocken. Drosera 2006 1/2:27-34.

7. Degryze S, Six J, Paustian K, Morris SJ, Paul EA, Merckx R: Soil organic carbon pool changes following land-use conversions. Global Change Biology 2004, 10:1120-1132.

8. Hooker TD, Compton JE: Forest ecosystem carbon and nitrogen accumulation during the first century after agricultural abandonment. Ecological Applications 2003, 13(2):299-313.

9. Post WM, Known KC: Soil carbon sequestration and land-use change: processes and potential. Global Change Biology 2000, 6:317-327.

10. Richter DD, Markewitz D, Trumbore SE, Wells CG: Rapid accumulation and turnover of soil carbon in a re-establishing forest. Nature 1999, 400:56-58.

11. Thuille A, Schulze E-D: Carbon dynamic in successional and afforested spruce stando in Thuringia and the Alps. Global Change Biology 2006, 12:325-342.

12. Paul KI, Polglase PJ, Nyakuengama JG, Khanna PK: Change in soil carbon following afforestation. Forest Ecology and Management 2002, 168:241-257.

13. Wilde SA, Iyer JG, Tanzer C, Trautmann WL, Watterston KG: Growth of Wisconsin coniferous plantations in relation to soils. University of Wisconsin. Madison, Research Bulletin 1965, 262:1-81.

14. Christensen BT: Physical fractionation of soil and organic matter in primary particle size and density separates. In Advances in soil science. Inc. 20 Edited by: Stewart BA. New-York: Springer-Verlag; 1992:1-90.

15. Flessa H, Amelung W, Helfrich M, Wiesenberg GLB, Gleixner G, Brodowski S, Rethemeyer J, Kramer C, Grootes PM: Storage and stability of organic matter and fossil carbon in a Luvisol and Phaeozem with continuous maize cropping: A synthesis. Journal of Plant Nurtrition and Soil Science 2008, 171:36-51.

16. John B, Yamashita T, Ludwig B, Flessa H: Storage of organic carbon in aggregate and density fractions of silty soils under different types of land use. Geoderma 2005, 128:63-79.

17. Chertov OG, Komarov AS: A model of soil organic matter dynamics. Ecological Modelling 1997, 94:177-189.

18. von Lützow M, Kögel-Knabner I, Ludwig B, Matzner E, Flessa H, Ekschmit K, Guggenberger G, Marschner B, Kalbitz K: Stabilization mechanisms of organic matter in four temperate soils: Development and application of a conceptual model. Journal of Plant Nutrition and Soil Science 2008, 171:111-124.

19. Wright SF, Franke-Snyder M, Morton JB, Upadhyaya A: Time-course study and partial characterization of a protein on hyphae of arbuscular mycorrhizal fungi during active colonization of roots. Plant and Soil 1996, 181:193-203.
20. Sauer D, Sponagel M, Giani L, Jahn R, Stahr K: Podzol: Soil of the year 2007. A review on its genesis, occurrence, and functions. Journal of Plant Nutrition and Soil Science 2007, 170:581-597.

21. Mendham DS, Heagney EC, Corbeels M, O'Connell AM, Grove TS, MCMurtrie RE: Soil particulate organic matter effects on nitrogen availability after afforestation with Eucalyptus globules. Soil Biology and Biochemistry 2004, 36(7):1067-1074.

22. Six J, Callewaert S, Lenders S, De Gryze S, Morris SJ, Gregorich EG, Paul EA, Paustian $\mathrm{K}$ : Measuring and understanding carbon storage in afforested soils by physical fractionation. Soil Science Society of America Journal 2002, 66:1981-1987.

23. Yamashita T, Flessa H, John B, Helfrich M, Ludwig B: Organic matter in density fractions of water-stable aggregates in silty soils: Effect of land use. Soil Biology and Boichemistry 2006, 38(11):3222-3234.

24. Billings SA: Soil organic matter dynamics and land use change at a grassland/forest ecotone. Soil Boilogy and Biochemistry 2006 38(9):2934-2943.

25. Don A, Scholten T, Schulze E-D: Conversion of cropland into grassland: Implications for soil organic carbon stocks in two soils with different texture. Journal of Plant Nutrition and Soil Science 2009, 172:53-62.

26. Lima AMN, Silva IR, Neves JCL, Novais RF, Barros NF, Mendonca ES, Smyth TJ, Moreira MS, Leite FP: Soil organic carbon dynamics following afforestation of degraded pastures with eucalyptus in southeastern Brazil. Forest Ecology and Management 2006, 235(1-3):219-231.

27. Chertov OG: Ecology of Forest Lands. Soil-Ecological Studies of Forest Sites Moscow: Nauka (Science Publication); 1981. (in Russian)

28. Chertov OG, Komarov AS, Nadporozhskaya MA, Bykhovets SA, Zudin SL: Simulation study of nitrogen supply in boreal forests using model of soil organic matter dynamics ROMUL. In Plant Nutrition - Food Security and Sustainability of Agro-Ecosystems Edited by: Horst WJ, et al. Boston London: Kluwer Dordrecht: 2001:900-901.

29. Golchin A, Oades JM, Skjemstad LO, Clarke P: ${ }^{13}$ C NMR-spectroscopy in density fractions of an oxisol under forest and pasture. Australian Journal of Soil Research 1995, 33(1):59-76.

30. Chertov OG, Menshikova GP: About influence of acid precipitation on the forest soils. Isvestiya AN UdSSR 1983, 6:906-913. (in Russian)

31. Bird JB, Kleber M, Torn MS: ${ }^{13} \mathrm{C}$ and ${ }^{15} \mathrm{~N}$ stabilization dynamics in soil organic matter fractions during needle and fine root decomposition. Organic Geochemistry 2008, 39:465-477.

32. Golchin A, Oades JM, Skjemstad LO, Clarke P: Soil structure and carbon cycling. Australian Journal of Soil Research 1994, 32(5):1043-1068.

33. Swanston CW, Caldwell BA, Homann PS, Ganio L, Sollins P: Carbon dynamics during a long-term incubation of separate and recombined density fractions from seven forest soils. Soil Biology and Biochemistry 2002, 34:1121-1130.

34. Swanston CW, Torn MS, Hanson PJ, Southon JR, Garten CT, Hanlon EM, Ganio L: Initial characterization of processes of soil carbon stabilization using forest stand-level radiocarbon enrichment. Geoderma 2005 , 128:52-62.

35. Cerli C, Celi L, Kaiser K, Guggenberger G, Johansson M-B, Cagnetti A, Zanini E: Changes in humic substances along an age sequence of Norway spruce stands planted on former agricultural land. Organic Geochemistry 2008, 39(9):1269-1280.

36. National Parks of Russia: Edited by Chebakova I.V Moscow: Biodiversity conservation centre; 1996. (in Russian)

37. Shishov LL, Tonkonogov WD, Lebedeva JJ, Gerasimova MJ: Russian soil classification Smolensk: Oykumena; 2004. (in Russian)

38. IUSS Working Group WRB: WRB 2006. World Soil Res. Repts. 103. FAO, Rome 2006.

39. Wright SF, Upadhyaya A: A survey of soils for aggregate stability and glomalin, a glycoprotein produced by hyphae of arbuscular mycorrhizal fungi. Plant and Soil 1998, 198:97-107.

40. Halvorson JJ, Gonzales JM: Bradford reactive soil protein in Appalachian soils: distribution and response to incubation, extraction reagent and tannins. Plant and Soil 2006, 286:339-356.

41. Bradford MM: A rapid and sensitive for the quantitation of microgram quantitites of protein utilizing the principle of protein-dye binding. Analytical Biochemistry 1976, 72:248-254.

42. Leifeld J, Kögel-Knabner I: Soil carbon matter fractions as early indicators for carbon stock changes under different land-use? Geoderma 2005, 124:143-155. 
43. Schmidt MWI, Rumpel C, Kögel-Knabner I: Evalution of an ultrasonic dispersion procedure to isolate primary organomineral complexes from soils. European Journal of Soil Science 1999, 50:87-94.

44. North PF: Towards an absolute measurement of soil structural stability using ultrasound. Journal of Soil Science 1976, 27:451-459.

45. Stevenson FJ: Humus chemistry: genesis, composition, reactions New York: Wiley; 1982.

46. Fookeu U: Huminsären in Oberflächensedimenten der Nordsee: Indikatoren für terrestrischen Eintrag? In Ph.D. Thesis University Oldenburg, Germany; 2000.

47. Senesi N, D'Orazio V, Ricca G: Humic acids in the first generation of EUROSOILS. Geoderma 2003, 116:325-344.

48. Kaiser K, Eusterhues K, Rumpel C, Guggenberger G, Kögel-Knabner I: Stabilization of organic matter by soil minerals - investigations of density and particle-size fractions from two acid forest soils. Journal of Plant Nutrition and Soil Science 2002, 165:451-459.

49. Chenu C, Plante AF: Clay-sized organo-mineral complexes in a cultivation chronosequence: revisiting the concept of the "primary organo-mineral complex". European Journal of Soil Science 2006, 57:569-607.

50. Magid J, Gorissen A, Giller KE: In search of the elusive "active" fraction of soil organic matter: three size-density fractionation methods for tracing the fate of homogeneously C-14-labelled plant materials. Soil Biology and Biochemistry 1996, 28:89-99.

51. Rovira P, Casals P, Romanya J, Bottner P, Couteaux M, Vallejo R: Recovery of fresh debris of different sizes in density fractions of two contrasting soils. European Journal of Soil Biology 1998, 34:31-37.

52. Rovira P, Ramon Vallejo V: Physical protection and biochemical qualità of organic matter in Mediterranean calcareous forest soils: a density fractionation approach. Soil Biology and Biochemistry 2003, 35:245-261.

doi: 10.1186/1750-0680-5-1

Cite this article as: Kalinina et al., Dynamics of carbon pools in post-agrogenic sandy soils of southern taiga of Russia Carbon Balance and Management 2010, 5:1

Submit your next manuscript to BioMed Centra and take full advantage of:

- Convenient online submission

- Thorough peer review

- No space constraints or color figure charges

- Immediate publication on acceptance

- Inclusion in PubMed, CAS, Scopus and Google Scholar

- Research which is freely available for redistribution

Submit your manuscript at www.biomedcentral.com/submit
C Biomed Central 